\title{
HUBUNGAN PENGGUNAAN ALAT KONTRASEPSI SUNTIK DENGAN SIKLUS MENSTRUASI PADA AKSEPTOR KB SUNTIK YANG PERIKSA DI POLINDES MAYANG
}

\author{
Oleh : \\ Tunjung Sri Yulianti ${ }^{1}$, Apresia Murtati ${ }^{2}$, Ratna Dwi Maryanti ${ }^{3}$
}

\begin{abstract}
Introduction: Indonesia is the world's 5th State with estimated population, namely 249 million. With fertility rates or Total Fertility Rate (TFR) 2.6, Indonesia was still above the average TFR ASEAN countries namely 2.4. The Agency's data on population and family planning (BKKBN) National shows that by 2013 there 8.500.247 (Fertile Age Couples) who are participants in a new and almost KB half $4.128 .115(48,56)$ using a method of contraception injections. (Department of health, 2013) Almost all contraceptives have side effects. At a time when researchers conduct interviews beginning on the check Acceptor in Polindes Mayang, Gatak, Sukoharjo, most mothers who use contraception injections said that their menstrual cycles become irregular.

The purpose: To know the relation of the use of contraception injections with menstrual cycle on the Acceptor KB in Polindes Mayang.

The method: The research design with analytic research, with correlation test statistic Chi Squared or $X^{2}$ with $p$ value of 0.05 .

The results: There is a relationship between the use of contraception injections with menstrual cycle on the Acceptor KB in Polindes Mayang with Pearson Chi Square value of $0.001 \mathrm{p}$ (probability 0.05 ) the magnitude of the relationship 0,536 or $53,6 \%$.

Conclusion: There is a relationship between the use of contraception injections with menstrual cycle on the Acceptor KB in Polindes Mayang.
\end{abstract}

Keywords: contraception injections, menstrual cycle

\section{PENDAHULUAN}

Indonesia menjadi negara dengan penduduk terbanyak, jauh di atas 9 negara ASEAN lain. Dengan angka fertilitas atau Total Fertility Rate (TFR) 2,6 , Indonesia masih berada di atas rata rata TFR negara ASEAN yaitu 2,4 .

Data SDKI (Survai Demografi dan Kesehatan Nasional) menunjukkan tren Prevalansi Penggunaan Alat Kontrasepsi atau Contraceptive Prevalence Rate (CPR) di Indonesia sejak 1991-2012 cenderung meningkat, sementara tren Angka Fertilitas atau Total Fertility Rate
(TFR) cenderung menurun. Tren ini menggambarkan bahwa meningkatnya cakupan wanita usia 15-49 tahun yang melakukan KB sejalan dengan menurunnya angka fertilitas nasional.

Data Badan Kependudukan dan Keluarga Berencana Nasional (BKKBN) menunjukkan bahwa pada tahun 2013 ada 8.500.247 PUS (Pasangan Usia Subur) yang merupakan peserta KB baru, dan hampir separuhnya 4.128 .115 $(48,56 \%)$ menggunakan metode kontrasepsi suntikan. (DepKes, 2013) 
Hampir semua alat kontrasepsi mempunyai kelebihan maupun efek samping. Efek samping yang sering dikeluhkan adalah perdarahan, keputihan, peningkatan berat badan, mual-muntah, pusing dan beberapa keluhan lain.

Dari hasil survei awal pada ibu yang periksa di Polindes Mayang di ketahui bahwa ada 45 orang akseptor KB. Sebagian besar ibu yang menggunakan kontrasepsi suntik mengatakan bahwa siklus haid mereka menjadi tidak tentu.

\section{TUJUAN PENELITIAN}

Tujuan penelitian ini adalah mengetahui hubungan penggunaan alat kontrasepsi suntik dengan siklus menstruasi pada akseptor KB suntik yang periksa di Polindes Mayang.

\section{DESAIN PENELITIAN}

Penelitian ini merupakan penelitian analitik dengan desain penelitian korelasi. Peneliti melibatkan dua variabel yaitu variabel yang pertama adalah pemakaian alat kontrasepsi suntik sebagai variabel bebas atau variabel independen dan variabel kedua adalah siklus menstruasi sebagai variabel terikat atau dependen.

\section{POPULASI, SAMPEL DAN TEKNIK SAMPLING}

Populasi dalam penelitian ini adalah seluruh ibu yang memakai alat kontrasepsi suntik yang periksa di Polindes Mayang sejumlah 35 orang. Peneliti mengambil seluruh populasi sebagai sampel sehingga dalam penelitian ini peneliti menggunakan teknik sampling jenuh.

\section{HASIL PENELITIAN}

Berdasarkan penelitian yang telah dilakukan mulai bulan Desember 2014 sampai dengan Februari 2015 didapatkan hasil sebagai berikut :
Tabel 1

Distribusi frekuensi penggunaan alat kontrasepsi

\begin{tabular}{|c|c|c|c|}
\hline No & $\begin{array}{l}\text { Penggunaan } \\
\text { Alat } \\
\text { Kontrasepsi } \\
\text { Suntik }\end{array}$ & f & $\%$ \\
\hline 1 & 1 bulan & 3 & 8,6 \\
\hline 2 & 3 bulan & 32 & 91,4 \\
\hline 3 & Jumlah & 35 & 100 \\
\hline
\end{tabular}

Dari tabel 1 di atas dapat diketahui bahwa sebagian besar responden menggunakan alat kontrasepsi suntik dengan jangka waktu 3 bulan yaitu 32 orang $(91,4 \%)$ dari 35 responden.

Tabel 2

Distribusi frekuensi siklus menstruasi

\begin{tabular}{cccc}
\hline No & $\begin{array}{c}\text { Siklus } \\
\text { menstruasi }\end{array}$ & $\mathrm{f}$ & $\%$ \\
\hline 1 & Polimenore & 1 & 2,8 \\
\hline 2 & Normal & 3 & 8,6 \\
\hline 3 & $\begin{array}{c}\text { Oligomenorea- } \\
\text { Amenorea }\end{array}$ & 31 & 88,6 \\
\hline 4 & Jumlah & 35 & 100 \\
\hline
\end{tabular}

Dari tabel 2 di atas dapat diketahui bahwa sebagian besar responden mengalami perubahan siklus menstruasi oligomenorea-amenorea yaitu 31 responden $(88,6 \%)$ dari 35 responden.

Berdasarkan analisa univariat siklus menstruasi kategori oligomenorea, diperoleh hasil nilai Mean adalah 44,19 hari. Sedangkan nilai minimal siklus menstruasi adalah 20 hari dan nilai maksimal siklus menstruasi adalah 4380 hari yang berarti masuk kategori amenorea.

Dari tabel Case Processing Summary menunjukkan diperoleh nilai Pearson Chi Square yaitu $\mathrm{p}=$ 0,001 (probabilitas $<0,05$ ) sehingga $\mathrm{Ha}$ diterima, yang berarti ada hubungan antara penggunaan alat kontrasepsi suntik dengan siklus 
menstruasi pada akseptor KB suntik yang periksa di Polindes Mayang. Besarnya hubungan 0,536 atau $53,6 \%$ yang menunjukkan besarnya hubungan sedang.

\section{PEMBAHASAN}

Berdasarkan data karakteristik responden, diperoleh informasi bahwa sebagian besar responden (27 orang) berada pada usia kurang dari 40 tahun dan sebagian besar (18 orang) memiliki pendidikan SMA/SMK dan Perguruan Tinggi. Hartanto (2004) memaparkan bahwa dalam hal memilih metode kontrasepsi dapat dilihat dari dua sudut pandang yaitu sudut pandang calon akseptor dan petugas medis. Dari pihak aseptor akan mempertimbangkan efektivitas dan keamanannya. Dengan tingkat pendidikan yang cukup memungkinkan responden lebih mudah memahami informasi mengenai segala hal yang terkait dengan kontrasepsi. Responden akan mencari informasi tentang efektifitas dan keamanan dari alat kontrasepsi.

1. Penggunaan Alat Kontrasepsi Suntik.

Seluruh responden penelitian ini menggunakan alat kontrasepsi suntik. Alat kontrasepsi suntik lebih banyak dipilih karena penggunaannya yang cukup mudah dan efektif. Hal ini sesuai dengan yang dipaparkan oleh Everett, (2008) kontrasepsi suntik adalah bentuk kontrasepsi yang sangat efektif karena angka kegagalan penggunaannya lebih kecil. Hal ini karena wanita tidak perlu mengingat untuk meminum pil dan tidak ada penurunan efektivitas yang disebabkan oleh diare atau muntah. Kontrasepsi ini menyebabkan lendir servik mengental menghentikan sperma, sehingga daya tembus mengubah endomentrium menjadi tidak cocok untuk implantasi dan mengurangi fungsi tuba fallopi.

Pada peneletian ini ditemukan data bahwa jenis kontrasepsi suntik yang digunakan oleh sebagian besar responden adalah jangka waktu 3 bulan. Alasan responden memilih alat kontrasepsi suntik jangka waktu 3 bulan karena melihat keuntungan atau manfaatnya. Keuntungan tersebut antara lain karena sangat efektif, efek sampingnya sedikit dan dapat digunakan pada perempuan usia diatas 35 tahun sampai perimenopause. Hal ini dikuatkan pula oleh paparan dari Saifuddin, ed. (2006) bahwa keuntungan kontrasepsi suntik progestin (jangka waktu 3 bulan) adalah : sangat efektif untuk pencegahan kehamilan jangka panjang, tidak berpengaruh pada hubungan suami istri, tidak mengandung estrogen sehingga tidak berdampak serius terhadap penyakit jantung dan gangguan pembekuan darah, tidak memiliki pengaruh terhadap ASI, sedikit efek samping, membantu mencegah kanker endometrium dan kehamilan ektopik, menurunkan kejadian penyakit jinak payudara, mencegah beberapa penyebab penyakit radang panggul, menurunkan krisis anemia bulan sabit (sickle cell).

2. Siklus menstruasi

Berdasarkan analisis univariat diperoleh data sebagian besar responden yaitu 31 orang $(88.6 \%)$ mengalami oligomenoreaamenorea. Nilai Mean siklus mentruasi kategori oligomenorea adalah 44,19 hari, sedangkan 14 orang responden yang berada pada kategori amenorea mempunyai rentang waktu tidak haid antara 6 bulan - 12 tahun. 
Siklus menstruasi adalah jarak antara tanggal mulainya haid yang lalu dan mulainya haid berikutnya. (Wiknjosastro, ed., 2008) Sedangkan menurut Kusmiran (2012) umumnya siklus menstruasi terjadi secara periodik setiap 28 hari tetapi ada pula setiap 21 dan 30 hari. Polimenorea adalah sering menstruasi atau jarak siklus menstruasi yang pendek kurang dari 21 hari, oligomenorea adalah tidak adanya menstruasi untuk jarak interval yang pendek atau tidak normalnya jarak waktu menstruasi yaitu jarak siklus menstruasi 35 - 90 hari dan amenorea adalah tidak adanya menstruasi selama enam bulan atau selama tiga kali tidak menstruasi sepanjang siklus menstruasi sebelumnya. Pada penelitian ini 1 responden mengalami polimenorea, 3 responden mempunyai siklus menstruasi normal dan 31 responden mengalami oligomenorea-amenorea dengan rincian 17 orang mengalami oligomenorea dan 14 responden mengalami amenorea.

3. Hubungan Penggaan Alat Kontrasepsi Suntik dengan Siklus Menstruasi

Berdasarkan analisa bivariat dengan uji Chi-Square program SPSS versi 16.0 dengan $\alpha=5 \%$ (0.05) diperoleh $p$ sebesar 0.001 sehingga nilai $p<0.05$, yang berarti $\mathrm{Ha}$ diterima sehingga dapat diketahui bahwa ada hubungan antara penggunaan alat kontrasepsi suntik dengan siklus menstruasi pada akseptor KB suntik yang periksa di Polindes Mayang. Besarnya hubungan sebesar 0,536 atau $53,6 \%$ yang berarti besarnya hubungan sedang.
Menurut Kusmiran (2012) salah satu faktor yang mempengaruhi menstruasi adalah faktor hormon. Hormon yang mempengaruhi terjadinya haid pada seorang wanita yaitu Follicle Stimulating Hormone (FSH) yang dikeluarkan oleh hipofisis, estrogen yang dihasilkan oleh ovarium, Luteinnizing Hormone (LH) yang dihasilkan oleh hipofisis, serta progresteron yang dihasilkan oleh ovarium.

Kontrasepsi suntik adalah salah satu kontrasepsi hormonal yang dibuat untuk membatasi fungsi ovarium sehingga mencegah proses ovulasi, tidak terjadi kehamilan dan tidak ada siklus menstruasi. Seperti yang dipaparkan oleh Kusmiran (2012) kontrasepsi suntik berisi progestin yang membatasi pola perdarahan, berhubungan dengan tidak teraturnya menstruasi, episode peradarahan yang panjang, amenorrhea pada 12 bulan penggunaan.

Kondisi ini terjadi pada responden yang menggunakan KB suntik jangka waktu 3 bulan, yaitu ada 14 responden yang mengalami amenore antara 6 bulan sampai dengan 12 tahun. Menurut Hartanto (2004) suntikan yang berisi hormon progresteron yaitu : Depo Modroxprogresteron Asetat, Depo-Provera (DMPA) lebih sering menyebabkan perdarahan, perdarahan bercak dan amenore. Amenore pada DMPA tampaknya lebih sering terjadi pada akseptor KB dengan berat badan tinggi. Dalam penelitian ini, responden yang mengalami amenore mempunyai berat badan rata-rata $52,71 \mathrm{~kg}$ dan semuanya menggunakan alat kontrasepsi suntik jangka waktu 3 bulan.

Hal tersebut juga sesuai dengan paparan dari Saifuddin, ed. (2006) yaitu kontrasepsi suntik 
mengandung Depoprogestin yang merangsang hormon progesteron sehingga dapat mengubah kecepatan pengiriman sel telur di dalam tuba fallopi, endometrium menjadi tipis dan atrofi dengan berkurangnya aktifitas kelenjar yang menyebabkan siklus menstruasinya tidak lancar seperti polimenorea, oligomenorea dan amenorea akibat penggunaan obat-obat hormonal jangka panjang. Kondisi ini sesuai dengan yang dialami oleh responden, dimana 32 responden dalam penelitian ini menggunakan kontrasepsi suntik yang berisi progesteron jangka waktu 3 bulan, dengan rata-rata penggunaan alat kontrasepsi suntik cukup lama yaitu 31 bulan atau 2,58 tahun.

Kontrasepsi hormonal sebagian besar berisi obat yang merangsang hormon progesteron. Sedangkan menurut Kusmiran (2012), pada siklus menstruasi progesteron berfungsi menghambat pembentukan $\mathrm{FSH}$ (Folikel Stimulating Hormon) dan LH (Luteinizing Hormon). Dengan terhambatnya $\mathrm{FSH}$ maka pematangan sel telur terganggu sehingga ovulasi tidak terjadi. Dengan terhambatnya LH maka badan kuning akan mengecil dan menghilang yang berdampak pada berhentinya pembentukan hormon progesteron. Dengan berhentinya pembentukan hormon progesteron maka endometrium menjadi mengering dan selanjutnya terkelupas dan terjadi perdarahan. Hal ini sering akan menimbulkan perdarahan ringan (spotting).

Pada pemakaian kontrasepsi hormonal yang lama akan menyebabkan atrofi endometrium. Karena dengan berhentinya pembentukan progesteron akan mengganggu pemberian nutrisi kepada endometrium sehingga endometrium menjadi tipis dan atropi. Hal ini yang mendukung terjadinya amenore pada beberapa akseptor yang menjadi responden dalam penelitian ini.

Hasil penelitian ini secara umum sesuai dengan penelitian terdahulu yang dilakukan oleh Lesmana, et al. (2012) dimana responden yang memakai kontrasepsi suntik 3 bulan berpeluang 2,78 kali lebih tinggi untuk mengalami perubahan siklus menstruasi. Sedangkan dalam penelitian Yayuk (2013) di dapatkan hasil ada hubungan antara penggunaan kontrasepsi dengan siklus menstruasi pada akseptor KB suntik DMPA.

\section{KESIMPULAN}

Data penelitian menunjukkan 32 responden $(91,4 \%)$ menggunakan kontrasepsi suntik dan 31 responden $(88,6 \%) \quad$ mempunyai siklus menstruasi oligomenorea-amenorea. Hasil penghitungan Pearson Chi Square diperoleh nilai $p=0,001$ (probabilitas $<0,05$ ) sehingga dapat disimpulkan bahwa ada hubungan antara penggunaan alat kontrasepsi suntik dengan siklus menstruasi pada akseptor KB suntik yang periksa di Polindes Mayang, dengan besarnya hubungan 53,6\% .

\section{SARAN}

Perubahan siklus menstruasi adalah efek dari penggunaan alat kontrasepsi hormonal. Apabila efek itu sangat mengganggu maka akseptor disarankan untuk memilih jenis alat kontrasepsi yang lain atau alat kontrasepsi non hormonal. Perlu diberikan penyuluhan yang lengkap terkait dengan pemakaian alat kontrasepsi dan efek sampingnya terutama mengenai perubahan siklus menstruasi. Penelitian lebih 
lanjut perlu dilakukan dengan responden yang lebih besar dan memfokuskan pengamatan, misalnya mengaitkan karakteristik berat badan responden dan jangka waktu pemakaian alat kontrasepsi dengan perubahan siklus menstruasi pada akseptor KB suntik.

\section{DAFTAR PUSTAKA}

Everett, Suzanne. Buku Saku Kontrasepsi dan Kesehatan Seksual Reproduktif. Alih bahasa Niken Budi Subakti. Jakarta: EGC. 2008.

Handayani, Sri. Buku Ajar Pelayanan Keluarga Berencana. Yogyakarta: Pustaka Rihana, 2010.

Hartanto, Hanifah. Keluarga Berencana dan Kontrasepsi. Jakarta: Pustaka Sinar Harapan, 2004.

Kusmiran, Eny. Kesehatan Reproduksi Remaja dan Wanita. Jakarta: Salemba Medika, 2012.

Melani, Niken et al. Pelayanan Keluarga

Berencana (dilengkapi dengan penuntun belajar). Yogyakarta: Citramaya, 2010.

Saifuddin, Bari Abdul, ed. Buku Panduan Praktis Pelayanan Kontrasepsi Edisi 2. Jakarta : Yayasan Bina Pustaka Sarwono Prawirohardjo, 2006.

Sulistyawati, Ari. Pelayanan Keluarga Berencana. Jakarta: Salemba Medika, 2012.
Suyanto. Metodologi dan Aplikasi Penelitian Keperawatan. Yogyakarta: Nuha Medika, 2011.

Ulifah, Maria Kurnia Dewi. Buku Ajar Kesehatan Reproduksi dan Keluarga Berencana Untuk Mahasiswa Bidan. Jakarta: Trans Info Media, 2013.

Wiknjosastro, Hanifah, ed. IImu Kandungan. Jakarta: PT Bina Pustaka Sarwono Prawirohardjo, 2008.

Dinas Kesehatan. Situasi dan Analisis Keluarga Berencana. 2014.

Lasmana, Vera et al. Hubungan penggunaan alat kontrasepsi KB suntik dengan gangguan siklushaid di wilayah kerja Puskesmas Rantau Tijang Kecamatan Pugung Kabupaten Tanggamus tahun 2012. 2012.

Yayuk. Hubungan Pengguanan Kontrasepsi dengan Siklus Menstruasi Pada Akseptor KB Suntik DMPA di BPS Harijati Ponorogo. 2013.

1 Dosen AKPER Panti Kosala Surakarta

2 Mahasiswa AKPER Panti Kosala Surakarta

3 Mahasiswa AKPER Panti Kosala Surakarta 